\title{
Når taushetsplikt innebærer bevisforspillelse
}

\author{
I en helt fersk høyesterettsdom drøftes rekkevidden av legers taushetsplikt. Legen gnidde en pose med \\ narkotika mellom hendene for å ødelegge spor av DNA fra pasienten. Han er nå frifunnet i tre rettsinstanser \\ for tiltalen om bevisforspillelse.
}

Ole Kristian Losvik

losvik@gmail.com

Ole Kristian Losvik (f. 1982) er turnuslege ved St. Olavs hospital og bloggredaktør

i Tidsskriftet.

\section{PUBLISERT I BLOGGEN}

(6) 10.11. 2013

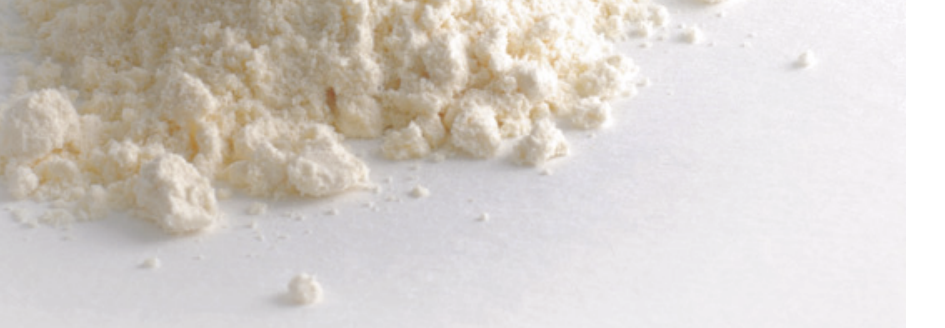

Colourbox

En januardag i 2012 ble politiet bedt om å komme til sykehuset for å ta hånd om en pose narkotika som var funnet på en intensivavdeling. Legen følte da et press for å oppgi pasientens identitet, noe han nektet. Politibetjenten forklarte at de ville undersøke den aktuelle posen med tanke på DNA-spor. Ved overleveringen av posen med det antatt narkotiske stoffet, tok legen posen $\mathrm{i}$ hånden $\mathrm{og}$ gned den mellom hendene. Deretter spurte legen om det var dette politiet mente med DNA.

Noen måneder senere mottok legen et forelegg som han nektet å vedta. Etter å ha vært innom tre rettsinstanser er nå saken ferdigbehandlet gjennom høyesterettsdommen som kom 6. november 2013. Selv om Høyesterett mener at legen med hensikt har forspilt bevis av betydning for politiets etterforskning, så har han handlet lovlig for å beskytte opplysninger fått under taushetsplikt.

\section{Fra Hippokrates til helsepersonellov} Legers taushetsplikt har nesten like gamle røtter som legekunsten selv. Allerede i den hippokratiske ed omtales en liknende plikt: «Alt som kommer til min viten under utøvingen av mitt yrke eller i daglig samkvem med mennesker, som ikke burde bli kjent for andre, vil jeg holde hemmelig og aldri avsløre.»

Uten at jeg tror forfatteren tenkte spesielt på narkotikasaker, ser vi at det tas et forbehold om at det bare er opplysninger «som ikke burde bli kjent for andre», som skal beskyttes. Domstolen har her ment at dette ikke var opplysninger som legen hadde plikt til å verne.

Om Hippokrates ikke er like aktuell lenger, er iallfall helsepersonelloven en nyere skrift som leger må forholde seg til. I helsepersonelloven $\S 21$ heter det: «Helsepersonell skal hindre at andre får adgang eller kjennskap til opplysninger om folks legems- eller sykdomsforhold eller andre personlige forhold som de får vite om i egenskap av å være helsepersonell.»

Formålet bak bestemmelsen finner vi i odelstingsproposisjon nr. 13 (1998-1999): «Formålet med taushetspliktbestemmelsene er å verne pasientens integritet og sikre befolkningens tillit til helsetjenesten og helsepersonell. Taushetspliktbestemmelsene skal hindre at pasienter unnlater å oppsøke helsetjenesten ved behov for helsehjelp. Pasienten skal føle seg trygg på at de opplysninger som gis i forbindelse med helsehjelpen ikke nyttes i andre sammenhenger.»

\section{Taushetsplikt også \\ for straffbare forhold}

Blant de sterkeste argumentene for taushetsplikt er at pasientene skal kunne gi informasjon til helsepersonell uten å være bekymret for at andre får innblikk i hva disse opplysningene inneholder. Man kan godt se for seg at pasienter vegrer seg for å fortelle om forhold som har medisinsk betydning fordi de innebærer noe straffbart.
Statens helsetilsyn skriver i rundskriv IK-25/91 om problemstillingen: «Hovedregelen er derfor at legen og dennes medhjelpere har taushetsplikt overfor politiet, også i forbindelse med narkotikasaker. Taushetsplikten vil omfatte alle opplysninger legen får om pasienters misbruk, herunder faktiske funn av narkotika. Taushetsplikten vil derfor som hovedregel være til hinder for at legen eller dennes medhjelpere gir opplysninger til politiet om narkotika som blir funnet i pasienters besittelse.»

Et forbehold er derimot nevnt i rundskriv 2012/007 fra Helsedirektoratet og Politidirektoratet: «Det kan imidlertid tenkes at meddelelse til politiet vil være nødvendig for å avverge alvorlig skade, enten på pasienten selv eller andre pasienter. Vilkårene vil kunne være til stede i en akutt situasjon, hvor meddelelse av opplysninger til politiet fremstår som eneste utvei for å redde noens liv eller hindre alvorlig helseskade. Ved kunnskap om at pasienten er i besittelse av «urent stoff» hvor skadepotensialet er stort, er det grunn til å tro at helsepersonellet rettmessig vil kunne melde fra.»

\section{Aktiv plikt - kan innebære bevisforspillelse} Dommen drøfter også hvor aktivt helsepersonell skal hindre uvedkommende å få tilgang til taushetsbelagt informasjon. Domstolen siterer odelstingsproposisjon $\mathrm{nr} .13$ (1998-1999), der det uttrykkes slik: «Taushetsplikten er ikke bare en passiv plikt til 
å tie, men også en aktiv plikt til å hindre uvedkommende i å få tilgang til taushetsbelagt informasjon. Forsvarlig håndtering og oppbevaring av pasientopplysninger er en forutsetning for å etterleve den lovbestemte taushetsplikten.»

Den aktive plikten til å bevare taushet begrenses av rammene for hva som er praktisk mulig. Slik jeg leser dommen, er det ikke noen generell plikt til å fjerne spor, men når legen ble gjort oppmerksom på at han kunne overlevere spor, var det rimelig å kreve at han gjorde dette - så fremt han hadde praktisk mulighet til det. Den enstemmige høyesterettsdommen viser at taushetsplikten står sterkt, og at plikten skal tolkes strengt. Den viser at det forventes at helsepersonell må forholde seg aktivt til den, og at de bør gå så langt det er praktisk mulig for å verne om taushetsbelagt informasjon.

Kommentarer til og diskusjoner om innlegget finner du på blogg.tidsskriftet.no Vil du blogge, ta kontakt. 